\title{
How We Lost the Women in Computing
}

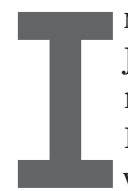

N JULY 2017, Google engineer James Damore distributed a memorandum titled "Google's Ideological Echo Chamber," which was critical of Google's diversity policies. The memo "went viral" and was widely distributed inside and outside of Google, leading to extensive media discussions. In August 2017, Google fired Damore for violation of the company's code of conduct. The U.S. National Labor Relations Board concluded that Google did not violate U.S. federal labor law when it fired Damore, but Damore filed a lawsuit against Google for discrimination.

The memo's central argument was that the gender disparity observed in the tech industry in general, and in Google in particular, could be partially explained by biological differences between women and men. In essence, argued Damore, women are less interested in computing then men. Ironically, over the past few years the historical role of women in computing has become much clearer. We cannot, I believe, understand the current gender disparity in computing without understanding the history of women in computing.

The critical roles played by Ada Lovelace and Grace Hopper are widely known. Lovelace worked closely with Charles Babbage, the British mathematician who was the first to conceive of general-purpose computers, and was first to realize that computers will have applications beyond pure calculation. Hopper was one of the first programmers of the Harvard Mark I computer and played a key role in the development of COBOL. But quite often Lovelace and Hopper are the only women to receive recognition for their significant role in computing history.
For example, it is less well known that seven women ${ }^{\mathrm{a}}$ were the world's first programmers, having programmed the ENIAC, the first general-purpose, electronic, programmable computer.

But the general ignorance of computing history goes deeper. The early programmers were women because until the development of electronic computers, computing used to be a human job; computers were humans who computed. Computing required precision and patience, and most pre-ENIAC human computers were female. Specifically, women played a key role in code breaking, which has had an intimate connection with computing. Three recent books describe this key role played by women in cryptology. Women Codebreakers at Bletchley Park, by Kerry Howard, ${ }^{\mathrm{b}}$ deciphers the legacy of British women codebreakers in World War II. Code Girls, by Liza Mundy, tells the story of over 11,000 women, who comprised more than $70 \%$ of all U.S. code breakers during that war. The Woman Who Smashed Codes: A True Story of Love, Spies, and the Unlikely Heroine Who Outwitted America's Enemies, by Jason Fagone, chronicles the life of Elizabeth Smith Friedman, who played a leading role in U.S. cryptanalysis for 40 years.

Another recent book, Brotopia, by Emily Chang, describes how "Silicon Valley disrupts everything but the Boys' Club." "From its earliest days," Chang writes, "the industry has self-selected for men: first, antisocial nerds, then, decades later, self-confident and risk-taking bros." As a prelude, I suggest reading the Vanity Fair disputed excerpt, featuring Chang's reporting about "exclusive, drug-fueled, sex-laced parties"

\footnotetext{
a https://goo.gl/8AvX9G

b https://goo.gl/WX2shx

c https://goo.gl/gmLMVU
}

where women are preyed upon. But the controversial sex parties are a small part of Silicon Valley's problems. The main story of the book is of a culture is that highly hostile to women.

A.T. Wynn and S.J. Correll, two Stanford sociologists, reach the same conclusion in their recent paper in $\mathrm{So}^{-}$ cial Studies of Science, titled "Puncturing the pipeline: Do technology companies alienate women in recruiting sessions?"d Using original observational data from recruiting sessions hosted by technology companies, they found that company representatives often engage in behaviors known to create a chilly environment for women. They concluded that representatives "may puncture the recruiting pipeline, lessening the interest of women at the point of recruitment into technology careers."

One may think these problems are specific to Silicon Valley, but the recent \#MeToo movement made it clear that academic environments can also be hostile to women. I urge you to read 'What Happens to Us Does Not Happen to Most of You, ${ }^{\mathrm{e}}$ where Kathryn McKinley provides "a personal account of sexism, harassment, and racism that I and some anonymous members of the computer-architecture community have experienced."

So how did we lose the women in computing? They did not just leave; they were pushed out. There is hard work ahead of us to start to undo the damage. Check out ACM SIGARCH's Committee to Aid REporting on discrimination and haraSsment (CARES) ${ }^{\mathrm{f}}$ and its diversity conversations $^{g}$ to see what the computer-architecture community is doing.
d https://goo.gl/sdxqwD
e https://goo.gl/zfDAco
f https://goo.gl/UgU2m9
g https://goo.gl/yuy3oU

Moshe Y. Vardi (vardi@cs.rice.edu) is the Karen Ostrum George Distinguished Service Professor in Computational Engineering and Director of the Ken Kennedy Institute for Information Technology at Rice University, Houston, TX, USA $\mathrm{He}$ is the former Editor-in-Chief of Communications.

Copyright held by author 